Review

\title{
Opportunities and perspectives for utilisation of co-products in the meat industry
}

\author{
Sarah A. Lynch ${ }^{\mathrm{a}, \mathrm{b}}$, Anne Maria Mullen ${ }^{\mathrm{a}}$, Eileen O'Neill ${ }^{\mathrm{b}}$, Liana Drummond ${ }^{\mathrm{a}}$, Carlos Álvarez ${ }^{\mathrm{a}, *}$ \\ ${ }^{a}$ Department of Food Quality and Sensory Science, Teagasc Food Research Centre, Ashtown, Dublin 15, Ireland \\ ${ }^{\mathrm{b}}$ Department of Food and Nutritional Sciences, University College Cork, Cork, Ireland
}

\section{A R T I C L E I N F O}

\section{Keywords:}

Meat co-products

Revalorisation

Offal

Sustainability

Protein extraction

\begin{abstract}
A B S T R A C T
Meat co-products are the non-meat components arising from meat processing/fabrication and are generated in large quantities on a daily basis. Co-products are considered as low added-value products, and in general it is difficult for industries to divert efforts into increasing their value. While many of these products can be edible those not used for human consumption or pet food is usually processed to be used as animal feed, fertilizer or fuel. However, to a large extent meat co-products are an excellent source of high nutritive value protein, minerals and vitamins and hence may be better diverted to contribute to alleviate the increasing global demand for protein. In this review the current uses, legislation and potential techniques for meat co-products processing are reviewed with the aim of showing a route to improve meat industry sustainability, profitability and better usage of available resources.
\end{abstract}

\section{Introduction}

The world population is predicted to grow by almost $35 \%$ in the next three decades, primarily in developing countries. This increasing population, coupled with rising living standards in developing countries, is expected to contribute to a higher demand for animal derived protein by 2050 (FAO, 2009). "Global meat production is projected to be 16\% higher in 2025 than in the base period (2013-15)" (FAO, 2009). The eating habits of populations, in developing countries, are shifting from a primarily grain-based diet towards diets containing more animal protein. For instance, in Asia, consumption of animal protein per capita increased by $225 \%$ between 1961 and 2011, while the consumption of crop based protein increased by only $22 \%$ in the same period (Boland et al., 2013). Worldwide animal protein now accounts for $40 \%$ of total protein consumption and this is expected to continue to rise (Sans \& Combris, 2015). It is predicted that by 2050 global meat production will need to increase by 200 million tonnes to a total of 470 million tonnes to meet demand (FAO, 2009). Animal protein consumption has increased worldwide from approximately $61 \mathrm{~g}$ per person per day in 1961 , to $80 \mathrm{~g}$ per person per day in 2011. This increase in animal protein consumption in developing countries has contributed to fulfilling the nutritional needs of the population (Sans \& Combris, 2015); where rapid population growth is more significant. Particularly in SubSaharan countries, the rate of meat consumption is growing much faster than in any other region (FAO, 2015). Pork is the most widely consumed meat in the world, followed by poultry, beef, and mutton. At a global scale, chicken is the fastest growing sector in this market (FAO, 2009). Regarding processed meat products, in developed countries products such as sausages, burgers and pies account for nearly half of all meat consumed (Kearney, 2010). The predicted increased meat production will bring a concomitant increase in the amounts of generated edible meat co-products or offal; which have been defined by the United Nations (2015) as "any product other than red or white meat muscles"; and processing streams (such as water from rendering processes, brines solution, exudates or drip loss). These processing streams are currently also underused as protein sources for human consumption, regardless of the fact that they are also excellent sources of minerals and vitamins (Mullen \& Álvarez, 2016). Several reasons may prevent offal from being used to their fullest potential, in spite of their benefits for human consumption. For instance, consumers' perception relating to what constitutes high quality meat; cultural or traditional practices of direct consumption; dietary, religious or ethical restrictions (Hsieh \& Ofori, 2011); or issues of public health such as BSE. Also, from a technical point of view, some barriers such as economy of scale, market knowledge, and know-how need to be addressed. Notwithstanding their uses as human food, meat co-products are extensively used in pet food, animal feed, pharmaceutical and biomedical industries, research, or diverse industrial applications (as glue, plant growth promoter, textile, cosmetic, novel materials or flocculants for water treatment).

\footnotetext{
* Corresponding author.

E-mail address: Carlos.alvarez@teagasc.ie (C. Álvarez).
} 
Better use of animal co-products has the potential to reduce the environmental impact of an increasing meat production, while providing new ingredients and products (Henchion, McCarthy, \& O'Callaghan, 2016). Moreover, if the entire edible protein content from farmed animals was employed as source of protein, the need for larger numbers of livestock could be minimised without compromising the protein requirements of the global population; thereby, reducing the environmental impact of farming.

Although efforts to recover protein from co-products have been ongoing for some time (Gault \& Lawrie, 1980; Lawrie \& Ledward, 1988); the development of processes to recover protein from these sources has regained interest in recent years, as a means to increase the value of slaughterhouse co-products by extracting protein for use as a functional ingredient (Darine, Christophe, \& Gholamreza, 2011) or bioactive peptides (Lafarga, Álvarez, \& Hayes, 2017). The technical criteria for protein isolation remains the same: ease of extraction to isolate proteins in a non-denatured state or peptides with biological activity; absence of undesirable compounds such as anti-nutritional factors, colour or flavoured compounds; high protein solubility over a wide $\mathrm{pH}$ range and ionic strength; and a suitable amino acid profile (Boland et al., 2013).

In addition to the technical properties, regulatory requirements (further discussed in Section 3) included in the legislative framework, need to be observed. In many cases, when a product is produced as part of primary food processing, that product would be called a by-product. However, according to EU regulations, the term animal by-product refers specifically to "any part of the animal carcass or any material of animal origin not intended for human consumption". In some cases animal by-products may be products of animal origin that may be destined for human consumption, but following a decision made by an operator, which shall be irreversible, are destined for purposes other than human consumption (European Parliament and Council, 2009).

The efficient utilisation of animal co-products and low value meats is important for the sustainability of the meat industry as a whole. It has been previously estimated that for the beef industry, almost one eighth of gross income derives from the effective utilisation of co-products (Lui, 2002); and hopefully, by means of innovative processes and novel applications, the amount of co-product utilised for human food, and other higher added-value applications, can be increased.

\section{Overview of offal current situation}

\subsection{Offal yield and composition}

The weights of a selection of bovine, ovine and porcine co-products are shown in Table 1. The gender, age, species and live weight of the animal have a significant influence on the weight of the co-product.
Offal and animal co-products account for approximately $30 \%$ of the live weight of pigs and $44 \%$ of the live weight of bovine (Marti, Johnson, \& Mathews, 2011). For instance, the yield of blood and organs is $12 \%$ of the live weight of bovine and $14 \%$ in pigs, when porcine rinds are included (Ockerman \& Basu, 2014).

With the exception of hair, wool, horns and digestive material, most non carcase material is edible, provided that these products are handled and processed according to the current legislation. However, due to their low or neutral market value, many edible co-products are redirected for purposes other than human consumption (Ockerman \& Basu, 2014). The nutritional profile and proximate composition of animal co-products may differ significantly to those in lean meat. Blood has higher moisture content $(78-82 \% \mathrm{w} / \mathrm{v}$ depending on the species) than lean meat; on the other hand, heart, kidney and lungs have a moisture content similar to the lean meat. Due to their physiological function, some co-products such as liver and kidney contain carbohydrate; for instance in liver, where carbohydrates are found in form of glycogen, it can account for between $8.5 \%$ (beef) and $15 \% \mathrm{w} / \mathrm{w}$ (chicken) of live weight, the content in glycogen in other co-products usually is lower than 1\%; which are the same levels that can be found in meat cuts. Co-products are a good source of protein with values ranging from around $15 \%$ for tongue, to $20 \%$ for liver (Anderson, 1988); values comparable to those found in lean meat (16-19\%). There are, however, differences in the amino acid profile of lean meat and co-products; for example, percentage of essential amino acids (\%EAA) in blood is $61 \%$ of total protein content for bovine and $58 \%$ for porcine; which is significantly higher when compared to lean meat (\%EAA about 50\%). On the other hand, tissues rich in connective tissue (CT) are deficient in EAA, as for example skin or ears, where $93 \%$ and $71 \%$ of total protein content is CT (Mullen \& Álvarez, 2016); and therefore contain a higher content of proline and glycine (highly abundant in collagen) than that found in lean meat. While overall the protein and amino acid content of co-products is similar to lean tissue, there are some notable differences in the essential amino acid composition of some co-products; in particular tripe, which has lower levels of valine, threonine, isoleucine, leucine, phenylalanine and methionine. Lung is also lower in threonine, isoleucine, leucine and methionine. Overall, methionine is the limiting amino acid for most co-products, with the lowest levels seen in pancreas, tripe, tongue, lungs and kidney. The vitamin content of coproducts is generally higher than that of lean meat, for example, liver is rich in vitamin $\mathrm{A}, \mathrm{B}_{12}$ and folate. Regarding mineral content, except for tripe, all products have a content of iron and copper that is higher than that of lean meat (Mullen \& Álvarez, 2016).

Further information about offal and meat co-products composition can be obtained from Mullen and Álvarez (2016) and from the United States Department of Agriculture Food Composition Databases (https://

Table 1

Expected weight of co-products based on animal type and weight.

\begin{tabular}{|c|c|c|c|c|c|c|}
\hline & Porcine & \multicolumn{4}{|l|}{ Bovine } & Sheep \\
\hline Animal Weight (kg) & $60-75$ & $200-300$ & $300-500$ & $300-600$ & $400-450$ & $55-65$ \\
\hline Bones $(\mathrm{kg})$ & $3.5-5.6$ & $30-42$ & $40-55$ & $40-65$ & $45-52$ & $4.0-6.0$ \\
\hline Head (kg) & $3.6-4.5$ & $16-24$ & $24-40$ & $24-48$ & $32-35$ & $5.5-6.5$ \\
\hline Feet $(\mathrm{kg})$ & $1.0-1.5$ & $4-6$ & $6-10$ & $6-12$ & $8-9$ & $1.1-1.3$ \\
\hline Blood (liters) & $3.5-3.8$ & $14-16$ & $18-25$ & $18-36$ & $24-26$ & $1.5-1.8$ \\
\hline Liver(g) & $1150-1660$ & $2700-4800$ & $3500-6200$ & $3000-8600$ & $5180-6400$ & $900-2200$ \\
\hline Lungs\& Trachea(g) & $750-1100$ & $2240-2570$ & $3980-6640$ & $6000-8600$ & $3480-6710$ & $700-2000$ \\
\hline Tongue $(\mathrm{g})$ & $150-210$ & $1500-1750$ & $1400-1880$ & $1380-1490$ & $1570-1940$ & $500-600$ \\
\hline Rumen \& Reticulum $(\mathrm{g})$ & & & $6340-10,600$ & $6000-15,500$ & $8470-10,350$ & $2900-4600$ \\
\hline Omasum(g) & & & $1800-4860$ & $5120-8700$ & $4310-5270$ & $1000-1200$ \\
\hline Abomasum(g) & & & $1000-3030$ & $2140-4700$ & $2230-2730$ & \\
\hline
\end{tabular}

Adapted from Spooncer 1988; Mullen and Álvarez, 2016. 
Table 2

Culinary uses of offal (Bovine (B), Porcine (P) Ovine (O) and Veal (V)).

\begin{tabular}{|c|c|c|}
\hline Co-product & Species & Use/Preparation \\
\hline Heart & B V P O & $\begin{array}{l}\text { Stuffed with forcemeat and braised Roasted, Grilled, } \\
\text { used in sausages and faggots, processed meats }\end{array}$ \\
\hline Kidney & B V P O & $\begin{array}{l}\text { Whole or sliced, grilled, braised or sautéed, used in } \\
\text { pies }\end{array}$ \\
\hline Liver & B V P O & $\begin{array}{l}\text { Sliced and sautéed } \\
\text { Liver sausage, pate, terrine, faggots, forcemeats }\end{array}$ \\
\hline Lung & Р O B & $\begin{array}{l}\text { Blanch, slice thinly fry in clarified butter } \\
\text { Sausages, braised, haggis, faggots, hash, stew }\end{array}$ \\
\hline Stomach & B P V O & $\begin{array}{l}\text { Tripe cooked in court bouillon and sliced } \\
\text { Used as casings } \\
\text { Poaching, braising, sausages } \\
\text { Caul used in pates, terrines, and to wrap lean meats for } \\
\text { roast }\end{array}$ \\
\hline Intestines & $\mathrm{P}$ & Sausage casings \\
\hline Muzzle/snout & B P & Brine, boil slice \\
\hline Tongue & B P V O & Fresh or pickled braised or boiled, potted meats \\
\hline Bones & & $\begin{array}{l}\text { Production of stocks and bouillon, marrow, gelatin } \\
\text { production }\end{array}$ \\
\hline Pancreas & $\mathrm{B} \mathrm{V} \mathrm{O}$ & Sweetbreads- sautéed, poached in white stock \\
\hline Tail & B & Soups, stew, stock, cook in stock, press and slice \\
\hline Blood & $\mathrm{P} \mathrm{V}$ & $\begin{array}{l}\text { Sausage, pudding, stews, plasma and red blood cells, } \\
\text { plasma transglutaminase, used for binding and colour }\end{array}$ \\
\hline Feet & $\mathrm{POV}$ & Pickled, fresh cooked in white stock, pressed and sliced \\
\hline Ears & $\mathrm{PO} \mathrm{V}$ & Boil with mirepoix, slice for salad, fried, stuffed \\
\hline Skin/hide & P B & Gelatin production \\
\hline Fat & & Suet \\
\hline
\end{tabular}

Adapted from (Saulnier and Brunet 1982; Rust 1988; Spooncer 1988; Marchello and Marchello 2005; Tarté 2009).

ndb.nal.usda.gov/ndb/search/list).

\subsection{Current uses and consumption}

Co-products provide a range of foods that are nutritionally valuable, with a variety of flavours and textures. However, products considered as a delicacy in one culture, might be completely rejected in another (Toldrá, Mora, \& Reig, 2016). The main factors influencing the utilisation of animal co-products for human consumption are regulatory requirements, consumer acceptability, nutritional benefits and economics (Goldstrand, 1988). Table 2 summarizes the main culinary uses of the most common meat co-products. According to Nollet and Toldrá (2011), in spite of increasing meat consumption, the use of co-products for human consumption has globally decreased.

While consumption patterns vary depending on factors such as culture, tradition and need, some general trends can be observed. In European countries liver from pork, lamb and beef is highly appreciated for its high nutritional value; bovine heart is used in traditional gastronomy in Peru; while in Brazil chicken hearts are usually roasted or grilled. Beef tongue is highly appreciated in Russia, Japan, Mediterranean countries and in some South American countries such as Brazil and Uruguay. Kidneys, from pork, lamb or beef, are extensively consumed in the United Kingdom. Beef tripe is used in traditional dishes in Scotland, Rumania, Turkey, Bulgaria and Spain; while porcine tripe is extensively used as casings for stuffing semidry and dry-fermented products. In Latin American countries, such as Mexico, and in Caribbean countries as Cuba, tripe is used to cook "mondongo". Finally, in China, a cold appetizer is made using beef tripe. Chitterlings, (intestines and rectum from pigs) are extensively used in most porkfarming countries; for instance in China, East Asian countries, Italy, France and African-American cultures, where many traditional dishes use this co-product as the main ingredient (Nollet \& Toldrá, 2011).

In African countries all edible co-products are processed and consumed as human food. For instance, in South Africa, delicacies from coproducts are accepted as traditional dishes. In Angola, for example, offal is accepted and consumed by people of all ages (Alao, Falowo, Chulayo, \& Muchenje, 2017). In Korea, China and Singapore offal from bovine, duck, pork and chicken are usually used as main ingredients for soups, or simmered in soy sauce. In Japan, offal from large animals is scarcely used for religious reasons, while chicken offal is widely used after grilling. In the Philippines, almost all parts from pork are used for eating purposes. In India, Pakistan, Nepal and Bangladesh offal from goat such as feet, head, testicles or tongue are consumed. A dish made with lamb brain is popular in Lebanon. Iran dishes may include liver, heart and kidneys from sheep in certain type of kebab (Nollet \& Toldrá, 2011).

In addition to their culinary and nutritional uses, co-products have also been used in a variety of fields including manufacture of furniture adhesives (Charles, 2003), as well as medical (Pearl, 2005) and surgical (Maverick Biosciences, 2015) uses, as shown in Table 3. Research into the utilisation of animal co-products in a variety of industrial

Table 3

Industrial, pharmaceutical, veterinary and medical uses of offal.

\begin{tabular}{|c|c|c|c|}
\hline Product & Industrial uses & Product & Pharma, veterinary and medical uses \\
\hline Stomach & Pet food, glue & Heart & $\begin{array}{l}\text { Valves for surgery } \\
\text { Pericardium used is surgery and for repair }\end{array}$ \\
\hline Intestines & Sausage casing & Stomach & $\begin{array}{l}\text { Digestive enzymes (pepsin, rennin, lipase, trypsin) } \\
\text { Hormones }\end{array}$ \\
\hline Bones & $\begin{array}{l}\text { Mineral extraction, gelatin, pet food, } \\
\text { collagen }\end{array}$ & Liver & Bile, heparin \\
\hline Blood & Glue/adhesive, fertilizer, feed, bio-plastics & Blood & $\begin{array}{l}\text { Cell culture media, vaccine stabilizer, diagnostics, blood plasma, blood serum, blood albumin, } \\
\text { fibrinogen films used in surgery, treatment of osteoarthritis and inflammation infection, wound } \\
\text { cleaning, thrombin }\end{array}$ \\
\hline Feet & Glue production & Bones & $\begin{array}{l}\text { Mineral extraction } \\
\text { Gelatin } \\
\text { Cartilage used in surgery }\end{array}$ \\
\hline Kidney & Pet food & Pancreas & Insulin, Glucagon, pancreatic enzyme supplements \\
\hline Liver & Pet food & Intestines & $\begin{array}{l}\text { Mucosa used for the production of heparin } \\
\text { Internal surgical sutures }\end{array}$ \\
\hline Lung & Pet food & Lung & Heparin \\
\hline Hide/skin & Leather, pet food, Gelatin for cosmetics & Skin & Gelatin Collagen Dressings, grafts initial treatment of burns \\
\hline Ears & Pet food & Adrenal gland & Cortisteroids, epinephrine, norepinephrine \\
\hline Fat & $\begin{array}{l}\text { Soap, lubricants, paints, emulsifiers, } \\
\text { shampoo, ink, glue, solvents, }\end{array}$ & Blood vessels & Used in surgery \\
\hline Collagen & Cosmetics & Collagen & Scaffolds for cell growing \\
\hline
\end{tabular}

Addapted from: Ockerman and Basu, 2014; Bier et al. 2012; Charles 2003; García-Falcón \& Simal-Gándara, 2005; Goldstrand 1988; Lambuthy, 2003; Lin and

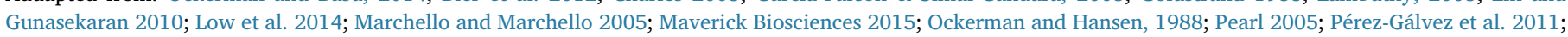
Torrallardona et al. 2002; Zeugolis et al., 2008. 
applications continues, as for instance to be used as bio flocculants (Piazza \& Garcia, 2010; Zhang, Garcia, \& Piazza, 2017).

\section{Legislation}

Offal is defined by EU legislation as "fresh meat other than that of the carcase, including viscera and blood" and is subject to the same regulations as carcass meat as outlined in EC Regulation No. 853/2004, laying down specific hygiene rules for food of animal origin (The European Parliament and the Council of the European Union, 2004). Viscera refer to the organs of the abdominal, thoracic and pelvic cavities, including the trachea and oesophagus.

Specific rules apply for the handling of all animal parts intended for human consumption, with a strong focus on traceability and safety assurance. Traceability ensures that all parts of an animal (including collected blood) are identifiable, and that, should one animal be declared unfit for human consumption, a batch containing parts from that animal will also be declared unfit. Chilling of the carcase and its parts must be carried out promptly, to ensure a continuous decrease to a final temperature of no $>3{ }^{\circ} \mathrm{C}$ for offal and lower than $7^{\circ} \mathrm{C}$ for carcases.

If offal or meat is intended for freezing, it should be frozen without undue delay while taking into account a stabilisation period before freezing (The European Parliament and the Council of the European Union, 2004).

In the European Union, the term animal by-product (ABP) is reserved for products of animal origin that are not intended for human consumption. Use or disposal of ABPs is strictly controlled and materials are divided into categories 1,2 and 3 , according to the risk they pose, with category 1 being the highest risk to humans (The European Parliament and the Council of the European Union, 2009). Animal parts intended for human consumption must be segregated from materials classed as ABPs. If offal is to be declared fit for human consumption, the slaughterhouse must meet certain conditions so as to avoid contamination, such as separate rooms for the emptying and cleaning of stomachs and intestines (unless otherwise authorised by a competent authority) and the separation in space or time for a number of activities, including stunning and bleeding; evisceration and dressing; and packaging of offal.

In the United States the Code of Federal Regulations (CFR Title 9) is responsible for regulating the use of animals and animal products for human food. Products covered include ingredients of livestock or poultry origin from muscle tissue, which are skeletal or found in the edible organs (with or without the accompanying and overlying fat), portions of bone, skin, sinew, nerve, and blood vessels which normally accompany the muscle tissue, not separated in the process of dressing, meat by products; mechanically separated (species); and poultry products. Federal regulation (USDA-FSIS, 1999) provides the rules governing collection and processing of blood when intended for human consumption.

Regarding Australia and New Zealand, FSANZ (Food Standards Australia and New Zealand) is an independent statutory agency established in 1991. According to this organisation offal means those parts of the carcass such as blood, brain, heart, kidney, liver, pancreas, spleen, thymus, tongue, and tripe, but it excludes meat flesh, bone, and bone marrow; thus offal and meat are defined separately, and offal is not considered to be meat (Australia New Zealand Food Standards Code Standard 2.2.1 - Meat and Meat Products, 2016).

Requirements for the labelling of cut meat and offal in Europe are defined in Annex II (The European Parliament and the Council of the European Union, 2004). The packaging of offal and cut meat should be branded before leaving the slaughterhouse with an oval shaped identification mark indicating the country where the slaughterhouse is located, and the approval number of the establishment. Although offal forms part of the edible portion of slaughtered animals, and in the past has been referred to as non-carcase meat, for European labelling purposes the definition of meat has been restricted to skeletal attached muscles (The Commission of the European Communities, 2001). The addition of offal (heart, liver, tongue, kidney and lung) in any meat preparation must be declared separately in the list of ingredients, along with offal species and type. Offal should not be included in the calculation of the product's meat content (The Commission of the European Communities, 2001).

In Australia and New Zealand the presence of offal in foods must be declared in the list of ingredients or, if the food is not required to bear a label, declared to the purchaser. Besides, the presence of brain, heart, kidney, liver, tongue or tripe in a food must be declared as 'offal' or by the specific name of the type of offal; and the presence of any other type of offal in a food must be declared by the specific name of the type of offal. (Australia New Zealand Food Standards Code - Standard 2.2.1 Meat and Meat Products, 2016).

\subsection{Detection of animal co- products in meat products}

To ensure consumer confidence in food products, the description and labeling must be accurate trustworthy and reliable. This has particular importance in processed food products where ingredients are not easily identifiable (Primrose, Woolfe, \& Rollinson, 2010). Mixtures of meat with undeclared co-products pose a potential adulteration issue (Zhao, Downey, \& O'Donnell, 2014). Methods for the authentication of meat and meat products have been reviewed by Ballin (2010). Differences exist in the composition and protein profile of meat and offal, some of these characteristics are reflected in analysis methods such as analysis by quantitating infrared spectra (Al-Jowder, Defernez, Kemsley, \& Wilson, 1999; Zhao et al., 2014). In the case of connective tissue hydroxyproline, an amino acid accounting for $8 \%$ of collagen, is easily quantified by a colorimetric method (Kolar, 1990). Through this method, the inclusion of collagen-rich tissues in meat products can be detected as the percentage of collagen to total protein content. In lean meat, this percentage is much lower $(20 \%)$ (El, 1995) compared to these co-products e.g. skin (97\%) or ears (73\%).

Studies on detection of adulteration of fresh and frozen beef burgers with offal (heart, lung, kidney and liver) using ATR (attenuated total reflectance) spectroscopy with multivariate analysis, have had some success in distinguishing authentic and adulterated beef burgers (Zhao et al., 2014). Authentic beef burgers could be identified with $100 \%$ accuracy, and burgers that had been adulterated with heart, lung, liver and kidney at levels of $0-20 \%$ could be correctly classified as adulterated. Earlier work by Al-Jowder et al. (1999), demonstrated that beef meat, kidney and liver samples could be easily distinguished by their respective spectra. Samples that had been adulterated with levels higher than $10 \%$ of offal were correctly identified. In the quantification of offal added to a sample, samples adulterated with liver had a prediction accuracy of $96 \%$ and those including kidney in the formulation had a prediction accuracy of $95 \%$.

Histology has also been employed to determine the authenticity of processed meat products including hamburgers (Prayson, McMahon, \& Prayson, 2008a), tortellini (Ghisleni, Stella, Radaelli, Mattiello, \& Scanziani, 2010) and hotdogs (Prayson, McMahon, \& Prayson, 2008b). These authors determined the meat content in hotdogs and hamburgers, using a combination of staining and light microscopy. In addition to skeletal muscle, other tissue types including nerves, blood vessels, adipose tissue, bone and cartilage were found in both hamburgers and hotdogs, however brain tissue was not detected in either product. The application of histology to tortellini meat products also enabled detection of nerves, blood vessels, cartilage, mucosa of the upper digestive tract and glandular tissue. More recent tools are those based on immunological detection (Ofori \& Hsieh, 2017), proteomic approach (Woolfe, 2017), or PCR analysis (Ghovvati, Nassiri, Mirhoseini, Moussavi, \& Javadmanesh, 2009); either for the detection of the inclusion of non-meat proteins, or for detection of other species than those specified in the label.

According to The Commission of the European Communities (2011), 
a permanent marker (glyceroltriheptanoate (GHT)) must be added by processors of Category 1 (intended for incineration) and Category 2 (intended for use in fertilizers) animal by-products at a minimum inclusion level of $250 \mathrm{mg} / \mathrm{Kg}$ fat. The use of this marker prevents the fraudulent and improper use of animal by-products. A method for the detection of GHT based on gas chromatography (GC), with quantification using mass spectroscopy (MS), has been validated for dried meat and bone meal (von Holst, Boix, Bellorini, Androni, \& Serano, 2012). However, this method requires that processors of animal by-products fully comply with the addition of GHT at the appropriate levels. A study by Marchis, Amato, and Abete (2013), found that 8 out of 17 samples tested were not compliant with legislation, as GHT was quantified at levels below the recommended. Currently, there are no official or validated methods to detect adulteration in Category 3 animal by-products () (Zhao et al., 2014).

\section{Processes used in the recovery of protein from offal and low value meats}

The protein content of offal is comparable to that of meat; which gives them a strong economic potential as sources for the production of new added-value products and functional ingredients (Toldrá et al., 2016). However, protein recovery may be difficult due to the high content of connective tissue, which can account for $15-20 \%$ of the total protein, in products such as lungs or liver, and up to $>90 \%$, as in cartilages or hides. The main component of connective tissue, collagen, is a very stable protein resistant to common extraction methods; impeding other proteins from being recovered. Besides, extraction methods need to balance the yield of recovered protein with potential negative effects on the properties of extracted proteins.

A variety of processes have been applied for the recovery of whole proteins from offal and low value cuts, for applications such as meat analogues, extenders or as food ingredient and these are summarised in Table 4. The extraction processes include surimi-like process (Desmond \& Kenny, 1998), salt extraction (Nuckles, Smith, \& Merkel, 1990) and isoelectric solubilisation precipitation (ISP) also known as $\mathrm{pH}$ shift (Selmane, Christophe, \& Gholamreza, 2008). For example, recent research (Álvarez, Drummond, \& Mullen, 2018a), carried out at Ashtown Teagasc (Dublin, Ireland), focused on the recovery of proteins from blood plasma, ham exudates, brine solutions, hides, bovine lungs and a processing stream from fat rendering (also referred as stick water). Testing on the functionality of these proteins in a meat based system showed that, at inclusion levels of up to $10 \%$ of total protein content, there was no negative impact on the properties of the final product. Each one of the protein extracts were obtained by means of tailored processes. For example using specific enzymatic processes to solubilize and extract collagen based proteins from hides; selective precipitation of proteins present in brines by modifying the $\mathrm{pH}$ of the raw material, followed by centrifugation; or in the most simple manner by spray drying the raw material e.g. exudates from hams.

Where proteins are extracted from meat co-products to exploit their techno-functional properties in food formulations, aqueous solutions are the preferred buffers for extraction. This is for two main reasons: they do not have a negative impact on protein structure and functionality in the way organic solvents do, and these systems lend themselves to being food grade. Finally, soluble and insoluble proteins are usually separated by centrifugation (Aluko, 2004) and further stabilised by means of drying, vacuum packing or addition of preservatives, until final use. These products can be then added to food formulations, where they can perform several functional roles such as binders, emulsifiers or gelling agents.

On the other hand, when peptides or protein fragments are the final end product, other processes such as enzymatic hydrolysis (Linder, Fanni, Parmentier, Sergent, \& Phan-Tan-Luu, 1995), alkaline hydrolysis (Gault \& Lawrie, 1980), acid hydrolysis (Dewitt, Gomez, \& James, 2002) or subcritical water hydrolysis (SWH) (Marcet, Álvarez, Paredes,
\& Díaz, 2016) can be employed. After protein hydrolysis, the desirable techno-functional properties may be lost, in particular gelling and water holding capacity; while other properties such as solubility can be improved. The most interesting aspect of hydrolysates is that novel bioactivities can be unlocked, leading to a new range of products. After peptides have been generated, membrane technologies and chromatographic techniques are commonly employed for their purification (Di Bernardini et al., 2011).

\subsection{Intact protein extraction}

\subsubsection{Surimi}

Surimi is a Japanese seafood product manufactured by washing fish mince, usually white fish. During the process, water soluble proteins, enzymes, blood and minerals are removed, improving the stability of the fish product and concentrating myofibrillar proteins (Antonomanolaki, Vareltzis, Georgakis, \& Kaldrymidou, 1999). After preparation, the product is mixed with cryoprotectants, to increase the protein stability (Wang \& Xiong, 1998) and frozen (Desmond and Kenny, 1998; Whitehead, Church, \& Knight, 1993). The surimi process results in a semi purified protein fraction with a high content of myofibrillar protein and has been applied, with some modifications, to the processing of poultry (Smyth \& Neill, 1997), red meat (McCormick, Burgen, Field, Rule, \& Busboom, 1993) and offal (Srinivasan \& Xiong, 1996). Muscle and offal from red meat generally contain higher fat, myoglobin, haemoglobin and connective tissue than fish (Park, Brewer, Mckeith, Bechtel, and Novakofski, 1996); resulting in differences in the yield and properties of the surimi product. For instance, due to the high content of myofibrillar protein, beef and porcine surimi result in strong and elastic gels when cooked (Park, Brewer, Mckeith, Bechtel, and Novakofski, 1996). Extraction yields using surimi processing vary depending on the properties of the original material. Some extraction yields previously reported include $45 \% \mathrm{w} / \mathrm{w}$ for lean beef; $38 \%$ for lean porcine; $18 \%$ for beef tongue, and $10 \%$ for beef cheek meat (Mckeith, Bechtel, Novakofski, Park, and Arnold, 1988). Surimi processing of hand boned mutton yielded a protein recovery of $42.5 \%$ of the initial protein, although yields were lower with mechanically separated mutton, due to sarcoplasmic protein loss in the wash water (McCormick, Burgen, Field, Rule, and Busboom, 1993). Depending on the processing conditions and on the characteristics of the starting material, connective tissue content in the surimi products may be concentrated. However, the content of connective tissue in the final product can be reduced if a screening process is used in the first wash, as collagen is removed before dewatering (Kang et al., 2007).

The water washing process in surimi production from minced beef has the effect of concentrating the levels of aspartic acid, threonine, serine, glutamic acid, alanine, methionine, isoleucine, leucine, tryptophan, phenylalanine, lysine and arginine. Histidine content, in the washed protein, was reduced compared to ground beef, and proline, glycine and valine were unchanged. In surimi processing of porcine muscle, glycine and histidine levels were lower than in the minced tissue, while aspartic acid, proline, alanine, valine and phenylalanine were unchanged. In beef and porcine surimi the non-protein nitrogenous compounds were removed in the washing process (Park, Brewer, Mckeith, Bechtel, and Novakofski, 1996). Researchers also reported that the washing process removes water soluble thiamine, as well as potassium, sodium and magnesium. However, calcium, copper, iron and zinc levels were unaffected by the process. This is probably due to the fact that these minerals are associated with structural or insoluble proteins and are thus retained, while water soluble minerals are more easily lost during the process. Water washing did not affect cholesterol content, although fat content was reduced in sheep meat surimi (Antonomanolaki, Vareltzis, Georgakis, \& Kaldrymidou, 1999; McCormick, Burgen, Field, Rule, and Busboom, 1993) and beef surimi (Park, Brewer, Mckeith, Bechtel, and Novakofski, 1996). These results suggest that the chopping and blending step leaves membranes 
Table 4

Methods used in the recovery of protein from animal co-products.

\begin{tabular}{|c|c|c|c|c|c|}
\hline Method & Advantages & Disadvantages & $\%$ Yields & Products used & Reference \\
\hline Surimi & $\begin{array}{l}\text { Protein concentrated and fat } \\
\text { content decreased }\end{array}$ & Low yields for some materials & $\begin{array}{l}45 \% \\
45 \% \\
38 . \% \\
18 \% \\
10 . \% \\
7.5 \%\end{array}$ & $\begin{array}{l}\text { Beef } \\
\text { Porcine } \\
\text { Beef Head } \\
\text { Beef Tongue } \\
\text { Beef Cheek } \\
\text { Beef Weasand Meat }\end{array}$ & Mckeith et al. (1988) \\
\hline Surimi & $\begin{array}{l}\text { WHC of surimi higher than } \\
\text { meat }\end{array}$ & $\begin{array}{l}\text { Cook bind of products lower } \\
\text { than those that used } \\
\text { phosphates }\end{array}$ & $42.5 \%$ & Mutton & McCormick et al. (1993) \\
\hline Surimi & $\begin{array}{l}\text { Colour improved, excellent } \\
\text { gels produced }\end{array}$ & $\begin{array}{l}\text { Water content of washed } \\
\text { muscle high }\end{array}$ & a & Sheep Meat & Antonomanolaki et al. (1999) \\
\hline Surimi & Collagen and fat reduced & Salt needed to form good gels & a & Beef Heart & James and Dewitt (2004) \\
\hline $\begin{array}{l}\text { Alkaline solubilisation/membrane } \\
\text { concentration/isoelectric } \\
\text { precipitation }\end{array}$ & $\begin{array}{l}\text { Low process cost } \\
\text { Good emulsification } \\
\text { properties }\end{array}$ & $\begin{array}{l}\text { Process impacts functional } \\
\text { properties }\end{array}$ & $\begin{array}{l}40 \% \\
48 \% \\
15 \%\end{array}$ & $\begin{array}{l}\text { Beef Lung } \\
\text { Porcine Lung } \\
\text { MDCM }\end{array}$ & $\begin{array}{l}\text { Selmane et al. (2008); Darine } \\
\text { et al. (2010, 2011) }\end{array}$ \\
\hline $\begin{array}{l}\text { Alkaline solubilisation/acid } \\
\text { precipitation }\end{array}$ & Inexpensive reagents/process & $\begin{array}{l}\text { Extraction and recovery yields } \\
\text { for some materials low }\end{array}$ & $\begin{array}{l}65 \% \\
60 \% \\
72 \% \\
58 \%\end{array}$ & $\begin{array}{l}\text { Meat Trimmings } \\
\text { And Bones } \\
\text { Bovine Lung } \\
\text { Rumen } \\
\text { Small Intestine } \\
\text { Large Intestine }\end{array}$ & $\begin{array}{l}\text { Hamilton, (1978) } \\
\text { Lynch, et al. (2017) } \\
\text { Gault and Lawrie, (1980) }\end{array}$ \\
\hline Alkaline solubilisation & Inexpensive reagents/process & $\begin{array}{l}\text { Extractability low with some } \\
\text { materials }\end{array}$ & a & $\begin{array}{l}\text { Bovine Lung } \\
\text { Rumen } \\
\text { Reticulum } \\
\text { Omasum } \\
\text { Abomasum } \\
\text { Ovine Lung } \\
\text { Stomachs }\end{array}$ & Young and Lawrie $(1974,1975)$ \\
\hline Acid Solubilisation & $\begin{array}{l}\text { Salt not needed to form good } \\
\text { gels }\end{array}$ & $\begin{array}{l}\text { Issues with using recovered } \\
\text { protein with injection process }\end{array}$ & $60.8 \%$ & Bovine Heart & $\begin{array}{l}\text { Dewitt et al. (2002); } \\
\text { James and Dewitt (2004); Vann } \\
\text { and Mireles Dewitt, (2007) }\end{array}$ \\
\hline Salt & Inexpensive reagents & $\begin{array}{l}\text { Highest yields with LIS - poor } \\
\text { functionality }\end{array}$ & $\begin{array}{l}45.5 \% \\
54.5 \% \\
70.1 \%\end{array}$ & $\begin{array}{l}\text { Beef heart } \\
\text { Beef lip } \\
\text { Beef skeletal muscle }\end{array}$ & Krasnowska et al. (1995) \\
\hline & $\begin{array}{l}\text { High ionic strength protein } \\
\text { impart best functionalities }\end{array}$ & $\begin{array}{l}\text { Low ionic strength proteins } \\
\text { reduce functionalities }\end{array}$ & $\begin{array}{l}53.1 \% \\
45.9 \% \\
75.3 \% \\
90.9 \% \\
61.8 \%\end{array}$ & $\begin{array}{l}\text { Beef heart } \\
\text { Beef lung } \\
\text { Beef spleen } \\
\text { Porcine liver } \\
\text { Porcine lung }\end{array}$ & Nuckles et al. (1990) \\
\hline Chemical hydrolysis & $\begin{array}{l}\text { High yield of soluble peptides } \\
\text { and amino acids }\end{array}$ & $\begin{array}{l}\text { Techno functional properties } \\
\text { lost due in hydrolysis. } \\
\text { Nutritive value reduced }\end{array}$ & $80 \%$ & $\begin{array}{l}\text { Porcine } \\
\text { haemoglobin }\end{array}$ & Álvarez et al. (2012) \\
\hline Enzyme hydrolysis & $\begin{array}{l}\text { High yield } \\
\text { Predictable peptide sequence }\end{array}$ & $\begin{array}{l}\text { Hydrolysis necessary for high } \\
\text { yield reduces functionality }\end{array}$ & $\begin{array}{l}60-80 \% \\
>64 \% \text { of } \\
\text { nitrogen }\end{array}$ & $\begin{array}{l}\text { Veal bone } \\
\text { Sheep viscera }\end{array}$ & $\begin{array}{l}\text { Linder et al. (1995); } \\
\text { Linder et al. (1996) } \\
\text { Bhaskar et al. (2007) }\end{array}$ \\
\hline Subcritical water hydrolysis & $\begin{array}{l}\text { No reagents required } \\
\text { Peptide size controlled }\end{array}$ & $\begin{array}{l}\text { High cost of equipment } \\
\text { Amino acid degradation }\end{array}$ & & $\begin{array}{l}\text { Porcine } \\
\text { haemoglobin }\end{array}$ & $\begin{array}{l}\text { Álvarez et al., (2012); Álvarez } \\
\text { et al., (2016) }\end{array}$ \\
\hline
\end{tabular}

\footnotetext{
a $\%$ recovery yield not given.
}

containing intact cholesterol. Preparation of water washed beef and porcine does, however, remove low molecular weight components, thereby concentrating myofibrillar proteins in the water washed product.

Surimi-like material from mutton has been used as a binder in restructured red meat products, as its water holding capacity (WHC) is higher than that of boned meat. The addition of $5 \%$ surimi reduced the amount of salt and phosphates needed to bind the final product, without affecting its quality. Moreover, sensory trials could not differentiate products with added surimi from those containing salt or phosphate (McCormick, Burgen, Field, Rule, and Busboom, 1993). The gelling properties of surimi from porcine skeletal muscle were better than those of heart surimi (Kang et al., 2007). Surimi from porcine heart had a lower WHC and gel strength than that of skeletal muscle, while cook loss was higher. Reduced WHC of cardiac muscle surimi may have affected gel forming ability and may be an indication that proteins from cardiac muscle were not dissociated enough with salt and phosphate, resulting in higher cook loss (Kang et al., 2007). Water binding capacity of surimi like material from sheep meat was greater than that of sheep meat itself, and this is likely due to a higher concentration of myofibrillar protein in sheep meat surimi and to the removal of sarcoplasmic proteins, which may interfere with the gelation properties of contractile proteins (Antonomanolaki, Vareltzis, Georgakis, \& Kaldrymidou, 1999). Surimi type material from beef hearts has potential in the manufacture of emulsion type sausages and inclusion at levels of $3 \%$ and above improves texture. Surimi material can be added at rate of up to $15 \%$ in frankfurter type products, giving reduced cook losses and lower shear values. Sensory analysis showed that tenderness increased with an addition of $7-15 \%$ surimi, while overall acceptability of frankfurters containing 7 and $10 \%$ surimi was higher than the control (Desmond and Kenny, 1998).

Although surimi from meat and offal has shown potential as functional ingredients in processed meats, there are unwanted interactions. Lipid oxidation in meat products was induced by the addition of beef heart surimi, and this was attributed to the levels of heme and iron, as well as unsaturated lipids. Thus the development of off flavours associated with lipid oxidation limits the potential of beef heart surimi (Desmond and Kenny, 1998; Kenney, Kastner, \& Kropf, 1992). 
Although some functional properties, such as gelling, emulsifying or binding capacity, of meat and offal are improved with surimi processing due to the concentration of myofibrillar proteins, these functional properties can be altered over the storage period. The emulsion properties of beef heart surimi, stored under refrigeration, were reduced over storage time due to a loss in protein surface hydrophobicity, while the elasticity of surimi protein gels increased with storage time. Progressive aggregation of myosin reduced the emulsifying properties, but enhanced the gelling properties of beef heart surimi during storage (Parkington et al., 2000). The use of cryoprotectants had a protective effect, increased water holding capacity and reduced cook loss of beef heart surimi over a frozen storage time of 24 weeks. Cryoprotectants also had a beneficial effect on other functional properties of beef heart surimi, such as the emulsion activity and stability and the solubility of proteins. Despite limiting protein conformational changes and denaturation, the addition of cryoprotectants promoted oxidation of lipids and protein side chains, and the use of antioxidants would be recommended.

Beef and porcine surimi are very popular in China and surrounding countries. Once the proteins have been extracted they are ball-shaped and used as main ingredients for soups or in traditional hot pots.

\subsubsection{Salt extraction}

Extraction of soluble protein from bovine co-products in aqueous saline solutions, and the further evaluation of their functional properties in the fractions obtained, has been carried out (Krasnowska, Gorska, \& Gergont, 1995; Nuckles, Smith, \& Merkel, 1990; Steen et al., 2016). A common approach was used across these studies, yielding a fraction with water soluble proteins (extracted using a sodium phosphate buffer at $\mathrm{pH}$ 7.4); and a fraction with salt soluble proteins (extracted using the same buffer with $0.6 \mathrm{M} \mathrm{NaCl}$ added).

The yield of this process is notably affected by the composition of the raw material. For instance, beef heart, lung and lip contained approximately $50 \%(\mathrm{w} / \mathrm{w})$ soluble protein fraction, composed mainly of actin and myosin (Krasnowska, Gorska, \& Gergont, 1995; Nuckles, Smith, and Merkel, 1990), while the remaining insoluble protein fraction was composed mainly of collagen; which is not solubilised by salt extraction. Skeletal muscle proteins, on the other hand, have an insoluble protein fraction of $<30 \%$ of the total weight, and the majority of the protein can be extracted as salt soluble protein. Pork liver had the lowest amount of insoluble protein (approximately 10\% of the total weight) corresponding also with the lowest collagen content (Steen et al., 2016). Characterisation of the protein fractions from co-products using SDS-PAGE shows that actin and myosin were not detected in the insoluble protein fraction (Nuckles, Smith, \& Merkel, 1990), while the water soluble fractions contain proteins in the molecular weight range that corresponds to myofibrillar fragments (Steen et al., 2016).

Evaluation of the functional properties of the co-products, in a frankfurter model food system, shows that higher levels of salt soluble protein had a beneficial effect on texture properties and reheat yields, conversely to water soluble proteins (Nuckles, Smith, and Merkel, 1990). Evaluation of the functional properties of protein extracted from skeletal muscle and co-products showed that co-products extracts do not perform as well as skeletal muscle extracts in the areas of emulsification or gelling. In all cases, salt soluble proteins performed better than water soluble proteins.

\subsubsection{Acid/alkali aided $p H$ shift}

This process exploits the $\mathrm{pH}$ dependent solubility of muscle proteins for the solubilisation and further precipitation of proteins. The solubilisation $\mathrm{pH}$, either acid ( 1 to 3 ) or alkaline (9 to 12 ), promotes the side chains of the protein to have a net positive (acid) or negative (alkaline) charge. As a consequence protein-protein interactions are reduced and protein water interactions are favoured and solubilisation of protein occurs. As a second step, solubilised proteins are precipitated by adjusting the $\mathrm{pH}$ value to the isoelectric $\mathrm{pH}$ (4 to 6) and then separated by centrifugation (Kristinsson, Theodore, Demir, \& Ingadottir, 2005). The method has been used extensively with co-products from fish (Kristinsson \& Ingadottir, 2006; Taskaya, Chen, \& Jaczynski, 2009; Vareltzis \& Undeland, 2012) and poultry processing (Hrynets, Omana, Xu, \& Betti, 2010; Omana, Xu, Moayedi, \& Betti, 2010). When employed for solubilising meat co-products, myofibrillar and sarcoplasmic proteins are extracted, while the subsequent application of filtration, press filtering or centrifugation removes a residue of connective tissue (Lynch, Álvarez, O'Neill, Keenan, \& Mullen, 2017). Protein ingredients produced using acid solubilisation in combination with filtration have been approved as generally recognised as safe (GRAS) in the USA. It is intended that the ingredient will be used in products of the same species from which it was derived. Ingredients derived from beef trimmings have been approved by the FDA for use as a water binding agent to improve moistness and reduce cook loss in beef products (Hibbert, 2009). Similar ingredients have also been approved from porcine (GRN 314), seafood (GRN 168) and poultry (GRN 147).

The factors affecting $\mathrm{pH}$ shift process are: $\mathrm{pH}$ value, time, temperature, solvent to sample ratio, raw material composition (Lynch, Álvarez, O'Neill, Keenan, \& Mullen, 2017) and salt concentration (Dewitt, Gomez, \& James, 2002). Extraction using high ratio of solvent to material results in a high extraction yield, with a low protein content solution, while extraction with lower ratios results in a viscous and high protein content solution with a low protein yield (Hamilton, 1978); such high viscosity has to be considered for further processing as filtration or pumping. The presence of $\mathrm{NaCl}$ increased the amount of protein soluble in the $\mathrm{pH}$ range of 4.5-5.0, but outside of these $\mathrm{pH}$ values, increasing $\mathrm{NaCl}$ content decreased protein extractability, indicating that protein extraction is most effective at low ionic strengths (Young \& Lawrie, 1974). Composition of material also affects the extractability and yield of protein from animal co-products. As previously described, collagen is very stable against extreme $\mathrm{pH}$ values, thus $\mathrm{pH}$ shift practically does not affect this protein. Raw materials with high collagen content reported lower yields of extraction than those with lower connective tissue (Gault \& Lawrie, 1980).

Extraction times above $2 \mathrm{~h}$ gave increased protein recovery, while increasing the extraction temperature led to an increase in the amount of collagen solubilised (Swingler \& Lawrie, 1979). Additionally, there was some concern that the increased extraction time and temperature may result in protein degradation and the generation of anti-nutritional factors such as the formation of lysinoalaine (LAL); however, it was not detected in protein extracted at $\mathrm{pH} 10$ for $8 \mathrm{~h}$ at temperatures below $40{ }^{\circ} \mathrm{C}$. Increasing the extraction temperature to $60^{\circ} \mathrm{C}$ led to the detection of LAL in the extract at all extraction times. While increasing extraction time did increase protein yields, extraction time above $2 \mathrm{~h}$ had little effect in increasing protein yield and co-products extracted at $20{ }^{\circ} \mathrm{C}$ for $2 \mathrm{~h}$ show over $50 \%$ protein extraction. In a recent investigation, using bovine and porcine lungs as raw material (Lynch, Álvarez, O'Neill, Keenan, \& Mullen, 2017), it was demonstrated that the most relevant parameters in protein extraction yield are $\mathrm{pH}$ and sample solvent ratio; while time and temperature, although statistically significant, had less effect on the overall yield. In this sense, for industrial applications, room temperature and extraction times no longer than $20 \mathrm{~min}$ are recommended. Studies on the effect of time and temperature on recovery of protein from bovine lung at fixed $\mathrm{pH}$ of 9.0 showed that there were nominal increases in yield with an increase in time and temperature (Darine, Christophe, \& Gholamreza, 2010), however increase in extraction time or temperature were not justified from an industrial application point of view, as differences disappeared when soluble protein was recovered by isoelectric precipitation.

Alkaline solubilisation of protein from slaughter house by-products was carried out by Selmane, Christophe, and Gholamreza (2008). Extraction at $20^{\circ} \mathrm{C}$ for $60 \mathrm{~min}$ at $\mathrm{pH} 9.0$ resulted in a protein solubility yield of $75 \%$ for porcine lung, $63 \%$ for beef lung and $83 \%$ for MDCM (mechanically deboned chicken meat). This proved that collagen, more abundant in bovine lung, plays an important role in the yield achieved. 
Subsequently, soluble protein can be recovered either by means of membrane technology or isoelectric precipitation. During the membrane filtration process fouling became an issue with MDCM after only $15 \mathrm{~min}$, under the filtration conditions assayed in this experiment, due to the high lipid content of the material. Fouling only became an issue with soluble bovine and porcine lung protein after $100 \mathrm{~min}$. The overall protein yield after filtration was $48 \%$ for porcine lung, $40 \%$ for beef lung and 15\% for MDCM. However, when soluble protein from MDCM was recovered by acid precipitation at $\mathrm{pH} 4-4.5$, a final protein yield of $55 \%$ was observed. These researchers found out as well, that processing conditions influenced functional properties; for instance, filtrate from porcine lung protein using $100 \mathrm{~nm}$ pore size began to gel at $45^{\circ} \mathrm{C}$ and had maximum gel strength of 35,000 Pa compared to a gel temperature of $58{ }^{\circ} \mathrm{C}$ and max gel strength of $30,000 \mathrm{~Pa}$ for proteins concentrated using pore size of $20 \mathrm{~nm}$. Similar results were found for beef lung. The emulsifying properties of beef and porcine lung protein compared favourably to commercial ingredients such as sodium caseinate and whey protein. Regarding MDCM, the lipid extraction process applied reduced functional properties with the exception of emulsifying properties. Comparison of the functional properties of beef lung purified using membrane filtration or isoelectric precipitation showed that precipitation is a suitable method and functional properties are similar to those of beef lung protein concentrates purified using filtration.

Acid solubilisation is an alternative to alkaline solubilisation. It has been used to recover protein with techno-functional properties from beef heart, which was selected as a model for red meats (Dewitt, Gomez, \& James, 2002). Process variables evaluated were: post mortem time, salt concentration and $\mathrm{pH}$. Post mortem time did not impact protein solubilisation and little difference was seen between 3 and $24 \mathrm{~h}$. This will enable a storage period for the collection of sufficient product to improve the economic viability and scale up of the process. The solubility of protein was, as in alkaline extraction, impacted by $\mathrm{pH}$ and salt content in solvent. The impact of salt addition was seen in protein solubilisation and recovery of soluble protein by precipitation, with the yield of total protein obtained at both stages decreasing as salt concentration increased.

Evaluation of proteins solubilised from beef heart as an alternative to phosphates was studied by Vann and Mireles Dewitt (2007). As a result, the level of salt added to the product including extracted proteins, was approximately half that added to the product manufactured using phosphates. However, a few disadvantages were observed: aerobic plate counts on day 9 values were significantly higher for steaks enhanced using soluble protein due to higher $\mathrm{NaCl}$ content in phosphate enhanced steaks; lipid oxidation products were significantly higher during shelf life for soluble protein enhanced steaks; and cook loss were significantly higher in protein enhanced steaks than those enhanced using phosphate. This indicates that although protein solubilised from beef heart show promise as functional ingredient, interactions with other ingredients need to be investigated to ensure that these protein extracts can be used by established food processing methods.

Due to the conditions used in the $\mathrm{pH}$ shift protein recovery process (acid or alkaline solubilisation followed by acid precipitation), this process potentially would have a beneficial effect on reducing microbial counts in the recovered protein. However, to the best of our knowledge, the most recent studies have been carried out mainly with fish proteins (Lansdowne, Beamer, Jaczynski, \& Matak, 2009a; Lansdowne, Beamer, Jaczynski, \& Matak, 2009b; Otto, Beamer, Jaczynski, \& Matak, 2011; Ronaghi, Beamer, Jaczynski, \& Matak, 2016); and no recent works assessing the impact of the extraction process on microbial load have been published using meat co-products. The impact of the $\mathrm{pH}$ shift process, using acid or alkaline solubilisation, on microbial aspects of animal co-products and their isolated proteins has been investigated by Swingler, Naylor, and Lawrie (1979). It was found that, in alkaline conditions, a decrease in bacterial growth at $30^{\circ} \mathrm{C}$ is seen when extraction $\mathrm{pH}$ is increased and, at least, a $90 \%$ reduction was seen when extraction $\mathrm{pH}$ was 10 , with the greatest reduction observed in the first $2 \mathrm{~h}$ of extraction. Regarding fish proteins, it has been reported that rainbow trout inoculated with Escherichia coli showed 4.4 log reduction under alkaline conditions ( $\mathrm{pH} 12.5)$. However, neither acid nor alkaline conditions were sufficient to produce a net pasteurisation effect for $E$. coli or Listeria innocua (Lansdowne et al., 2009a; Lansdowne et al., 2009b). Additionally, there is also some evidence to show that the acid used to precipitate proteins, from alkaline solubilised protein, influences the bactericidal effect of the process, depending on the acid employed (Ronaghi, Beamer, Jaczynski, \& Matak, 2016; Otto, Beamer, Jaczynski, \& Matak, 2011). Although it is evident that the pH shift process does result in a reduction of microbial populations, the process used for the recovery of protein does not eliminate these populations completely. Based on the results seen with $\mathrm{pH}$ shift process, there may be potential to increase the microbial reduction seen by optimising the $\mathrm{pH}$, time, temperature and type of acid in the process.

There is little information publically available about the industrial applications of this process. Proteus Industries, n.d (MA, USA) is using this technology to generate protein solutions or suspensions from fish, chicken and beef raw materials to be used as a coater for beef, chicken or fish before deep frying, reducing the fat content of the final product (Available at http://www.proteusindustries.com/). Additionally, protein beef extracted by means of acid solubilisation has been declared as GRAS in 2009 (GRAS Notice, 2009).

\subsection{Peptide extraction by means of hydrolysis}

Conversely to the methods discussed above, hydrolysis methods are based on breaking down the peptidic bonds of the proteins present in the raw material, yielding peptides and free amino acids. The proteins once transformed into peptides, which usually present a very high solubility, can be easily separated from non-hydrolysed proteins and further recovered by means of centrifugation, filtration or precipitation. Several methods have been employed for this purpose, in particular enzymes, strong acids or alkalis, or subcritical water.

\subsubsection{Enzymatic hydrolysis}

The most common methods employed for protein hydrolysis are those based on the use of enzymes. Typically, main factors affecting the hydrolysis process are processing time, $\mathrm{pH}$, temperature, enzyme specificity and protein/enzyme ratio. Many reviews have been published regarding the use of meat co-products and offal to generate peptides, either for its nutritional value, modified functional properties or for unlocking bioactivities such as antioxidant, antihypertensive, antimicrobial or metal biding ability (Bah, Bekhit, Carne, \& McConnell, 2013; Di Bernardini, et al., 2011; Lafarga, Álvarez, \& Hayes, 2017).

Controlling the degree of hydrolysis (DH) is essential to ensure the properties of the final hydrolysate. DH is the percentage of total peptidic bonds hydrolysed at the end of the process, assuming that $100 \%$ represents DH when the protein is fully transformed into free amino acids. Usually, high DH corresponds to very low molecular weight peptides; high content in free amino acids; an increased recovery yield of protein-nitrogen; a loss of functional properties; improved solubility and more bitter taste. For instance, enzymatic hydrolysis of veal bone was carried out and hydrolysis parameters were controlled to ensure that DH was not higher than $8 \%$ preventing the formation of bitter taste (Linder, Fanni, \& Parmentier, 1996).

Hydrolysis of sheep visceral mass, following heat treatment $\left(121^{\circ} \mathrm{C}\right.$ under pressure) and partially defatting, using a commercial fungal protease at neutral $\mathrm{pH}$ and moderate temperature yielded a nitrogen recovery of over $60 \%$, using an enzyme substrate ratio of $1 \%$ (Bhaskar, Modi, Govindaraju, Radha, \& Lalitha, 2007).

More recently, the use of in silico methods have been employed to identify peptides from specific substrates with targeted functionalities. Recent work by Lafarga, O'Connor, and Hayes (2015) identified peptides with PEP (prolyl endopeptidase) inhibitory function which has 
been linked to improved cognitive function. The work was based on the use of substrates containing proline from animal co-products including collagen, actin, myosin and serum albumin.

Blood proteins have attracted attention from researchers, particularly haemoglobin, to generate bioactive peptides. For example, according to Bah, Bekhit, Carne, and McConnell (2013), enzymatic hydrolysis of haemoglobin can lead to the generation of peptides, which are known to have antihypertensive, antioxidant, antimicrobial, mineral binding, reducing power, opioid, antigenotoxic, or bacterialgrowth stimulation activities. In on-going research, our group is trying to up-scale the enzymatic hydrolysis of red blood cells, to obtain antioxidant and antimicrobial peptides. Key parameters such as agitation, protein/enzyme ratio, and downstream processes are being evaluated to validate the results obtained at lab scale.

\subsubsection{Non-enzymatic hydrolysis}

Non-enzymatic hydrolysis has been utilised to recover amino acids and peptides from animal co- products by means of different techniques such as chemical hydrolysis employing strong acids and alkalis; or subcritical water hydrolysis (SWH), when high pressures and temperatures are combined to cleave the peptidic bonds. However, technofunctional properties are lost due to the process conditions, though an increased solubility is observed (Marcet, Álvarez, Paredes, \& Díaz, 2016). The resulting product can still have applications for nutritional supplementation (Álvarez, Rendueles, and Díaz, 2012). Generation of amino acids and peptides from the haemoglobin fraction of porcine blood has been achieved using both alkaline (Álvarez, Rendueles, \& Diaz, 2013) and acid hydrolysis (Álvarez, Rendueles, and Diaz, 2012). Acid hydrolysed proteins have applications as flavour enhancers and also in the area of biotechnology as microbiological and culture media. During acid hydrolysis essential amino acids tryptophan, methionine, cysteine are destroyed and glutamine and aspartame are converted to glutamic and aspartic acid. Alkaline hydrolysis is also destructive with serine and threonine amino acids being degraded; however, tryptophan is not lost during processing (Pasupuleti \& Demain, 2010). As the acid and alkaline hydrolysis processes are destructive to particular amino acids, it has been suggested that it would be beneficial to carry out separate acid and alkaline hydrolysis. By mixing the acid and alkaline hydrolysate the hydrolysis is stopped with little need for additional reagent to neutralise the $\mathrm{pH}$, and only serine, threonine, methionine and cysteine will be destroyed in the combined product (Álvarez, Rendueles, and Diaz, 2013). Amino acids and peptides have been recovered from poultry co-products (Zhu et al., 2010), blood proteins as haemoglobin and albumin (Álvarez, Tiwari, Rendueles, \& Díaz, 2016; Rogalinski, Herrmann, \& Brunner, 2005) and fish (Xian, Chao, Liang, \& Cheng, 2008) processing using sub-critical water hydrolysis. Water is maintained in its liquid state at temperatures above boiling point by applying high pressure. Under these conditions, proteins are released from the matrix and hydrolysed into peptides and free amino acids (Marcet, Álvarez, Paredes, \& Díaz, 2016). The value of animal co-products may be increased by recovering amino acids and peptides using the hydrolysis methods mentions above, however due to the loss of the native protein structure they will not have applications as a techno functional ingredient.

\subsection{Downstream processes}

After proteins have been extracted, either as peptides or as intact proteins, they need to be further processed in order to improve their stability; purity (presence of salts added during the extraction process or presence of undesired proteins); or to remove excess water to obtain a protein powder, easier to handle and to incorporate in product formulations.

Membrane technologies (ultrafiltration, nano-filtration, tangential flow filtration, dialysis, electro-dialysis or osmosis) are often used to remove salts and concentrate proteins of interest or to fractionate proteins according to their molecular size (Selmane, Christophe, and Gholamreza, 2008; Galanakis, 2012). In spite of the benefits that such technologies provide, some disadvantages have to be considered. The formation of a gel in the active surface of the membrane, which leads to a loss of efficacy in terms of permeation flux, is one of the main difficulties encountered. When flux restriction becomes severe, a cleaning step has to be performed, which delays the overall production process. Promising efforts to avoid this fouling effect have been proposed, as for example the use of functionalised membranes using graphene oxide (Kumar, Mcglade, Ulbricht, and Lawler, 2015); the application of magnetic fields perpendicular to the membrane (Zin et al.; 2016) or by using vibrating membrane technology (Mohammad, Ng, Lim, \& Ng, 2012).

Membrane technologies are used frequently as a pre-concentration step before the final drying process. Spray-drying is a well-established drying method for food ingredients, mainly because of its large processing capacity and relative ease to control and optimize. As an additional advantage, when compared to more traditional drying methods, the high temperature contact time is very short, helping to preserve heat-labile properties of the source material (Murugesan \& Orsat, 2012). However, when highly temperature-sensitive products need to be dried, freeze drying or lyophilisation might be the preferred technique, since no high temperature are involved, although the processing cost are significantly higher (Mumenthaler \& Leuenberger, 1991).

For bioactive peptides, chromatographic techniques can be applied in tandem with membrane filtration, to purify and concentrate specific compounds possessing the bioactivity of interest. Using these techniques compounds can be separated based on properties such as hydrophobicity, isoelectric point or charge characteristics. Frequently, more than one chromatographic technique is combined to obtain the targeted peptide (Di Bernardini et al., 2011). Although technically feasible, performing chromatographic separation at industrial scale is excessively expensive, and only suitable for very high added-value products.

\subsection{Emerging technologies and novel processes for protein extraction}

The methods described so far can be considered traditional or based in traditional techniques, such as solvent extraction, use of food grade enzymes, salting-in and salting-out effects, membrane filtration systems or protein solubilisation by $\mathrm{pH}$ modification. Such methods are very consistent and most of them have been broadly applied in the food industry for many different applications. However, some of these methods can be improved to achieve higher extraction yield; reduced water consumption; reduced microbiological load; or reduced processing times, by applying newer emerging processing technologies. When applying novel technologies, effects on the overall process, as well as any effects on the properties of the final product have to be considered. The most promising emerging technologies for intact protein processing are those classified as non-thermal, since processing at room temperature allow proteins to remain in their native state thus maintaining their properties (Smeller, 2002). For example, a recent investigation using fish as raw material (Álvarez, Lélu, Lynch, \& Tiwari, 2018), demonstrated that alkaline extraction assisted by ultrasound (US) can remarkably improve the extraction yield. The authors reported that novel sequential acid-alkaline extraction resulted in similar extraction levels compared to a single step assisted by US. A similar approach has been carried out in our facilities, with a view to increase the extraction yield of functional proteins from bovine and porcine lungs. Preliminary results (not yet published) indicate that ISP-US is able to increase the amount of proteins recovered (up to a $5-10 \%$ depending on extraction conditions) with no negative effect on the functional properties of the recovered proteins. Additionally, water consumption and use of chemicals $(\mathrm{NaOH}$, in this case) can be reduced, making this process more sustainable and environmentally friendly. 
On the other hand, when peptides and amino acid are the desired product, since these compounds are more thermo-stable, heat pretreatments can be used to improve the performance of the enzymes, exposing more cleavage points and providing a beneficial impact on the rate of hydrolysis, by assisting protein denaturation (Bhaskar, Modi, Govindaraju, Radha, \& Lalitha, 2007). A similar effect was observed when high hydrostatic pressure, which promotes protein denaturation, was applied to bovine blood before hydrolysis (Toldrà, Parés, Saguer, \& Carretero, 2011).

Many other promising emerging technologies, which are currently being investigated for extraction of a variety compounds from nonmeat-related co- and by-products, hold potential for applications in meat co-products processing. Examples include: pulse electric fields (PEF) (Sobrino-Lopez and Martin-Belloso, 2006); microwave assisted extraction (Ekezie, Sun, \& Cheng, 2017); aqueous two-phase solvent; ionic liquids; high voltage electrical discharges (HVED); or extraction assisted by hydrotropic solvents (Barba, Zhu, Koubaa, Sant'Ana, \& Orlien, 2016). When considering protein extraction from meat co-products it is important to review and explore potential technologies used for other raw materials. From our review of the literature, research with non-meat based proteins seems well progressed, and may provide opportunities for the meat industry to exploit.

As well as using emerging technologies, innovative processes can be designed based on the particular properties and characteristics of the raw material; either co-products, trimmings or processing streams. For example, a recent investigation carried out in our laboratory (data not published), succeeded in developing an innovative desalting method for a rendering processing stream which was of proteins with strong gelation properties. The stream was concentrated until a gel was formed, and this gel was subsequently submerged in cold water, allowing the salt to diffuse out. Results showed that $90 \%$ of the protein was recovered, $>85 \%$ of the salt was removed and the water consumption per unit of protein recovered was significantly lower when compared to traditional diafiltration. A recent publication discloses a method for optimised blood centrifugation (Álvarez, Drummond, \& Mullen, 2018b) based on red cell crenation. In this method, specific amounts of phosphate buffer saline are carefully added to freshly collected blood prior to centrifugation. The research demonstrated that very high quality blood plasma (i.e. very low haemolysis) can be obtained regardless the processing conditions employed: centrifugation volumes, speed or time. Besides, the amount of plasma proteins recovered per litre of blood was increased and the protein content in the red cell fraction was remarkably improved. Although this method has to be scaled-up and tested with a continuous centrifuge, reflective of industrial processing, there is a potential for this product to be used for high added-value markets e.g. research or pharmaceutical. An additional advantage is that one of the main issues of using plasma as food ingredient, the red colour imparted to the final products, can be more easily overcome.

\section{Non-food applications}

In spite of the efforts that have been made in developing new processes and new technologies for meat co-products utilisation, current industrial applications seem too limited and mainly dedicated to pet food and animal feed purposes. Table 3 summarizes current applications of several of these products, when not employed for human consumption. Depending on the final application and on the level of processing involved to obtain the product, the generated added value can be very low, as for example for fertilizers; or can reach significant commercial value as for enzymes and hormones (from stomach) or thrombin (from blood). For instance, a market study performed by MLA (Meat \& Livestock Australia) (Glenn, 2015) reported that the price of dried blood (blood meal) was 230 AUD/t; while haemoglobin meal was $3000 \mathrm{AUD} / \mathrm{t}$ and immunoglobulins was higher than 16,000 AUD/t, when intended as supplements in livestock feed formulations. For this reason, developing innovative applications and novel uses for proteins extracted from co-products, will lead to positive economic impact in the meat industry. For example, as part of ReValue Protein Project (www. revalueprotein.com), we have developed a new process (pending patent) to generate haemoglobin based films with tailored solubility and mechanical properties. Our analysis showed that these films can be used as carrier of bioactive compounds (antioxidant, antimicrobial, etc); as effective water vapour barrier; and even more relevant, as scaffolds for cells with potential uses in biomedical applications. Additionally, the method to make protein-based films insoluble can be applied to proteins extracted from other co-products, expanding their range of application.

\section{Conclusion}

The co-products generated as a result of meat processing account for a considerable amount of the edible portion of beef, porcine and sheep carcases. These co-products are a valuable source of protein with uses in culinary and food processing, and also in the fields of research, biomedicine and others, as demonstrated. As consumption of many coproducts in western diets has diminished, there is potential to recover proteins for use as food ingredients. The functional properties of recovered proteins are influenced by the characteristics of the raw material as well as by the recovery method and, processing conditions employed. Characterisation of the starting material and of the fractions derived during processing are essential for selection and development of the most efficient recovery method for high quality functional protein ingredient.

As extensively reported in this review, great efforts have been focused on protein extraction from vegetable, fish or even chicken sources; however, the number of publications related to protein extraction from meat co-products is still scarce. Taking into account the high volumes of co-products generated globally, the increasing need of protein for a growing population and the excellent nutritive value of offal proteins, it is worthwhile to explore all available techniques and processing methodologies to capitalise on the currently underused meat co-products, as a way to increase protein production and improve the environmental impact of the meat industry.

\section{Acknowledgments}

"This work forms part of the ReValueProtein Research Project (Grant Award No. 11/F/043) supported by the Department of Agriculture, Food and the Marine (DAFM) under the National Development Plan2007-2013 funded by the Irish Government."

\section{References}

Alao, B. O., Falowo, A. B., Chulayo, A., \& Muchenje, V. (2017). The potential of animal by-products in food systems: Production, prospects and challenges. Sustainability, 9(7), 1089.

Al-Jowder, O., Defernez, M., Kemsley, E. K., \& Wilson, R. H. (1999). Mid-infrared spectroscopy and chemometrics for the authentication of meat products. Journal of Agricultural and Food Chemistry, 47(8), 3210-3218.

Aluko, R. E. (2004). The extraction and purification of proteins: An introduction. In R. Y. Yada (Ed.). Proteins in food processing (pp. 323-351). Cambridge: Woodhead Publishing Limited.

Álvarez, C., Drummond, L., \& Mullen, A. M. (2018a). Protein recovered from meat coproducts and processing streams as pork meat replacers in Irish breakfast sausages formulations. LWT-Food Science and Technology, 96, 679-685.

Álvarez, C., Drummond, L., \& Mullen, A. M. (2018b). Expanding the industrial applications of a meat co-product: Generation of low-haemoglobin content plasma by means of red cells crenation. Journal of Cleaner Production, 185, 805-813.

Álvarez, C., Lélu, P., Lynch, S. A., \& Tiwari, B. K. (2018). Optimised protein recovery from mackerel whole fish by using sequential acid/alkaline isoelectric solubilization precipitation (ISP) extraction assisted by ultrasound. LWT- Food Science and Technology, $88,210-216$.

Álvarez, C., Rendueles, M., \& Diaz, M. (2012). The yield of peptides and amino acids following acid hydrolysis of haemoglobin from porcine blood. Animal Production Science, 52(5), 313-320.

Álvarez, C., Rendueles, M., \& Díaz, M. (2012). Production of porcine hemoglobin peptides at moderate temperature and medium pressure under a nitrogen stream. Functional 
and antioxidant properties. Journal of Agricultural and Food Chemistry, 60(22), $5636-5643$.

Álvarez, C., Rendueles, M., \& Diaz, M. (2013). Alkaline hydrolysis of porcine blood haemoglobin: Applications for peptide and amino acid production. Animal Production Science, 53(2), 121-128.

Álvarez, C., Tiwari, B. K., Rendueles, M., \& Díaz, M. (2016). Use of response surface methodology to describe the effect of time and temperature on the production of decoloured, antioxidant and functional peptides from porcine haemoglobin by subcritical water hydrolysis. LWT - Food Science and Technology, 73, 280-289.

Anderson, B. A. (1988). Composition and nutritional value of edible meat by- products. In A. M. Pearson, \& T. R. Dutson (Eds.). Edible meat by-products advances in meat research volume 5 (pp. 15-45). London: Elsevier Science Publishers LTD.

Antonomanolaki, R. E., Vareltzis, K. P., Georgakis, S. A., \& Kaldrymidou, E. (1999). Thermal gelation properties of surimi-like material made fromsheep meat. Meat Science, 52(4), 429-435.

Australia New Zealand Food Standards Code - Standard 2.2.1 - Meat and Meat Products (2016). Available at http://www.foodstandards.govt.nz/code/Documents/2.2 1\%20Meat\%20products\%20v157.pdf, Accessed date: January 2018.

Bah, C. S. F., Bekhit, A. E.-D. A., Carne, A., \& McConnell, M. A. (2013). Slaughterhouse blood: An emerging source of bioactive compounds. Comprehensive Reviews in Food Science and Food Safety, 12(3), 314-331.

Ballin, N. Z. (2010). Authentication of meat and meat products. Meat Science, 86(3), 577-587.

Barba, F. J., Zhu, Z., Koubaa, M., Sant'Ana, A. S., \& Orlien, V. (2016). Green alternative methods for the extraction of antioxidant bioactive compounds from winery wastes and by-products: A review. Trends in Food Science \& Technology, 49, 96-109.

Bhaskar, N., Modi, V. K., Govindaraju, K., Radha, C., \& Lalitha, R. G. (2007). Utilization of meat industry by products: Protein hydrolysate from sheep visceral mass. Bioresource Technology, 98(2), 388-394.

Bier, J. M., Verbeek, C. J. R., \& Lay, M. C. (2012). An ecoprofile of thermoplastic protein derived from blood meal part 2: Thermoplastic processing. International Journal of Life Cycle Assessment, 17, 314-324.

Boland, M. J., Rae, A. N., Vereijken, J. M., Meuwissen, M. P., Fischer, A. R., van Boekel, M. A., ... Hendriks, W. H. (2013). The future supply of animal-derived protein for human consumption. Trends in Food Science \& Technology, 29(1), 62-73.

Charles, L. P. (2003). Animal glues and adhesives. In A. Pizzi, \& K. L. Mittal (Eds.). Handbook of adhesive technology, revised and expanded (pp. 479-494). (2nd ed.). New York: Mercel Dekker Inc.

Darine, S., Christophe, V., \& Gholamreza, D. (2010). Production and functional properties of beef lung protein concentrates. Meat Science, 84(3), 315-322.

Darine, S., Christophe, V., \& Gholamreza, D. (2011). Emulsification properties of proteins extracted from beef lungs in the presence of xanthan gum using a continuous rotor/ stator system. LWT-Food Science and Technology, 44(4), 1179-1188.

Desmond, E. M., \& Kenny, T. A. (1998). Preparation of surimi-like extract from beef hearts and its utilisation in frankfurters. Meat Science, 50(1), 81-89.

Dewitt, C. A. M., Gomez, G., \& James, J. M. (2002). Protein extraction from beef heart using acid solubilization. Journal of Food Science, 67(9), 3335-3341.

Di Bernardini, R., Harnedy, P., Bolton, D., Kerry, J., O'Neill, E., Mullen, A. M., \& Hayes, M. (2011). Antioxidant and antimicrobial peptidic hydrolysates from muscle protein sources and by-products. Food Chemistry, 124(4), 1296-1307.

Ekezie, F. G. C., Sun, D. W., \& Cheng, J. H. (2017). Acceleration of microwave-assisted extraction processes of food components by integrating technologies and applying emerging solvents: A review of latest developments. Trends in Food Science \& Technology, 67, 160-172.

El, S. N. (1995). Evaluating protein quality of meats using collagen content. Food Chemistry, 53(2), 209-210.

European Parliament and Council (2009). Regulation (EC) No 1069/2009. Official Journal of the European Union, 300(April), 1-33.

FAO (2009). How to feed the world in 2050. Population and Development Review, 35.

FAO (2015). OECD-FAO Agricultural Outlook 2016-2025. Available at http://www.fao. org/3/a-BO100e.pdf, Accessed date: October 2017.

Galanakis, C. M. (2012). Recovery of high added-value components from food wastes: Conventional, emerging technologies and commercialized applications. Trends in Food Science \& Technology, 26(2), 68-87.

García-Falcón, M., \& Simal-Gándara, J. (2005). Polycyclic aromatic hydrocarbons in smoke from different woods and their transfer during traditional smoking into chorizo sausages with collagen and tripe casings. Food Additives and Contaminants, 22(1), 1-8.

Gault, N. F., \& Lawrie, R. A. (1980). Efficiency of protein extraction and recovery from meat industry by-products. Meat Science, 4(3), 167-190.

Ghisleni, G., Stella, S., Radaelli, E., Mattiello, S., \& Scanziani, E. (2010). Qualitative evaluation of tortellini meat filling by histology and image analysis. International Journal of Food Science and Technology, 45(2), 265-270.

Ghovvati, S., Nassiri, M. R., Mirhoseini, S. Z., Moussavi, A. H., \& Javadmanesh, A. (2009). Fraud identification in industrial meat products by multiplex PCR assay. Food Control, 20(8), 696-699.

Glenn, D. (2015). Blood Based Proteins: A market review for MLA, January 2015. Available at https://www.mla.com.au/download/finalreports?itemId =2796, Accessed date: January 2018.

Goldstrand, R. E. (1988). Edible meat products: Their production and importance to the meat industry. In A. M. Pearson, \& T. R. Dutson (Vol. Eds.), Edible meat by-products advances in meat research. Vol. 5. Edible meat by-products advances in meat research (pp. 1-13). London: Elsevier Applied Science Publisshers.

GRAS notice (2009). Available at http://wayback.archive-it.org/7993/ 20171031050438/https://www.fda.gov/downloads/Food/ IngredientsPackagingLabeling/GRAS/NoticeInventory/UCM269480.pdf, Accessed date: March 2018

Hamilton, R. G. (1978). Recovery of functional meat proteins from abattoir by-products. CSIRO Food Research Quarterly, 38, 6-12.

Henchion, M., McCarthy, M., \& O'Callaghan, J. (2016). Transforming beef by-products into valuable ingredients: Which spell/recipe to use? Frontiers in Nutrition, 3(November), 1-8.

Hibbert, R. (2009). Beef protein. Retrieved from https://www.fda.gov/downloads/Food/ IngredientsPackagingLabeling/GRAS/NoticeInventory/ucm269480.pdf, Accessed date: November 2017.

Hrynets, Y., Omana, D. A., Xu, Y., \& Betti, M. (2010). Effect of acid- and alkaline-aided extractions on functional and rheological properties of proteins recovered from mechanically separated turkey meat (MSTM). Journal of Food Science, 75(7), 477-486.

Hsieh, Y. H., \& Ofori, J. A. (2011). Blood-derived products for human consumption. Revelation and Science, 1(01), 14-21.

James, J. M., \& Dewitt, C. A. M. (2004). Gel attributes of beef heart when treated by acid solubilisation isoelectric precipitation. Journal of Food Science, 69(6), 473-480.

Kang, G. H., Yang, H. S., Jeong, J. Y., Moon, S. H., Joo, S. T., \& Park, G. B. (2007). Gel properties of surimi-like materials from cardiac and skeletal muscle of pigs. AsianAustralasian Journal of Animal Sciences, 20(8), 1292-1296.

Kearney, J. (2010). Food consumption trends and drivers. Philosophical Transactions of the Royal Society of London. Series B, Biological Sciences, 365(1554), 2793-2807.

Kenney, P. B., Kastner, C. L., \& Kropf, D. H. (1992). Muscle washing and raw material source affect quality and physicochemical properties of low-salt, low-fat, restructured beef. Journal of Food Science, 57(3), 545-550.

Kolar, K. (1990). Colormetric determination of hydroxyproline as measure of collagen content in meat and meat products: NMKL collaborative study. Association of Official Analytical Chemists, 73, 54-57.

Krasnowska, G., Gorska, I., \& Gergont, J. (1995). Evaluation of functional properties of offal proteins. Nahrung, 39(2), 149-155.

Kristinsson, H. G., \& Ingadottir, B. (2006). Recovery and properties of muscle proteins extracted from tilapia (Oreochromis niloticus) light muscle by $\mathrm{pH}$ shift processing. Journal of Food Science, 71(3).

Kristinsson, H. G., Theodore, A. E., Demir, N., \& Ingadottir, B. (2005). A comparative study between acid-and alkali-aided processing and surimi processing for the recovery of proteins from channel catfish muscle. Journal of Food Science, 70(4), 298-306.

Kumar, M., Mcglade, D., Ulbricht, M., \& Lawler, J. (2015). Quaternized polysulfone and graphene oxide nanosheet derived low fouling novel positively charged hybrid ultrafiltration membranes for protein separation. RSC Advances, 5(63), 51208-51219.

Lafarga, T., Álvarez, C., \& Hayes, M. (2017). Bioactive peptides derived from bovine and porcine co-products: A review. Journal of Food Biochemistry, 41(6), e12418.

Lafarga, T., O'Connor, P., \& Hayes, M. (2015). In silico methods to identify meat-derived prolyl endopeptidase inhibitors. Food Chemistry, 175, 337-343.

Lambuthy, A. (2003). Protein adhesives for wood. In A. Pizzi, \& K. L. Mittal (Eds.). Handbook of adhesive technology, revised and expanded (pp. 457-478). (2nd ed.). New York: Mercel Dekker Inc.

Lansdowne, L. R., Beamer, S., Jaczynski, J., \& Matak, K. E. (2009a). Survival of Escherichia coli after isoelectric solubilization and precipitation of fish protein. Journal of Food Protection, 72(7), 1398-1403.

Lansdowne, L. R., Beamer, S., Jaczynski, J., \& Matak, K. E. (2009b). Survival of listeria innocua after isoelectric solubilization and precipitation of fish protein. Journal of Food Science, 74(4), 201-205.

Lawrie, R. A., \& Ledward, D. A. (1988). Edible protein recovery and upgrading of meat packinghouse waste. In A. M. Pearson, \& T. R. Dutson (Eds.). Edible meat by-products advances in meat research volume 5 (pp. 231-260). London: Elsevier Applied Science Publisshers.

Lin, H., \& Gunasekaran, S. (2010). Cow blood adhesive: Characterization of physicochemical and adhesion properties. International Journal of Adhesion and Adhesives, 30(3), 139-144.

Linder, M., Fanni, J., \& Parmentier, M. (1996). Functional properties of veal bone hydrolysates. Journal of Food Science, 61(4), 712-716.

Linder, M., Fanni, J., Parmentier, M., Sergent, M., \& Phan-Tan-Luu, R. (1995). Protein recovery from veal bones by enzymatic hydrolysis. Journal of Food Science, 60(5), 949-952.

Low, A., Verbeek, C. J. R., \& Lay, M. C. (2014). Treating Bloodmeal with Peracetic acid to produce a bioplastic feedstock. Macromolecular Materials and Engineering, 299(1), 75-84.

Lui, D. C. (2002). Better utilization of by-products from the meat industry. Extension Bulletins. Food and Fertilizer Technology Center for the Asian and Pacific Region (FFTC Publication Database). http://www.agnet.org/library/eb/515/, Accessed date: March 2018 (2002-10-01).

Lynch, S. A., Álvarez, C., O'Neill, E. E., Keenan, D. F., \& Mullen, A. M. (2017). Optimization of protein recovery from bovine lung by $\mathrm{pH}$ shift process using response surface methodology. Journal of the Science of Food and Agriculture, 98(5), 1951-1960.

Marcet, I., Álvarez, C., Paredes, B., \& Díaz, M. (2016). The use of sub-critical water hydrolysis for the recovery of peptides and free amino acids from food processing wastes. Review of sources and main parameters. Waste Management, 49, 364-371.

Marchello, J. A., \& Marchello, E. V. (2005). Contributions to society: Slaughter by- products. In W. G. Pond, \& A. W. Bell (Eds.). Encyclopedia of animal science (pp. 258260). New York: Marcel Dekker.

Marchis, D., Amato, G., \& Abete, M. C. (2013). A monitoring study of glyceroltriheptanoate (GTH) in animal by-products through a validated GC-MS analytical method. Food Control, 34(2), 624-629.

Marti, D., Johnson, R., \& Mathews, K. (2011). Where's the (not) meat?: Byproducts from beef and pork production. USDA Economic Research Service. Retrieved December 2017, from https://www.ers.usda.gov/publications/pub-details/?pubid $=37428$. 
Maverick Biosciences (2015). Biological Medical Product Materials. Retrieved June 8, 2017, from http://maverickbio.com/biological-medical-device-materials/.

McCormick, R. J., Burgen, S., Field, R. A., Rule, D. C., \& Busboom, J. R. (1993). Surimilike products from mutton. Journal of Food Science, 58(3), 497-500.

Mckeith, F. K., Bechtel, P. J., Novakofski, J., Park, S., \& Arnold, J. S. (1988). Characteristics of surimi-like material from beef, pork and beef by-products. Proceedings of the 34th International Congress of Meat Science and Technology (pp. 325326). Australia: Brisbane.

Mohammad, A. W., Ng, C. Y., Lim, Y. P., \& Ng, G. H. (2012). Ultrafiltration in food processing industry: Review on application, membrane fouling, and fouling control. Food and Bioprocess Technology, 5(4), 1143-1156.

Mullen, A. M., \& Álvarez, C. (2016). Offal: Types and composition. The Encyclopedia of Food and Health: Academic Press, United Kingdom152-157.

Mumenthaler, M., \& Leuenberger, H. (1991). Atmospheric spray freeze-drying: A suitable alternative in freeze drying technology. International Journal of Pharmaceutics, 72 , 97-110.

Murugesan, R., \& Orsat, V. (2012). Spray drying for the production of nutraceutical ingredients-A review. Food and Bioprocess Technology, 5(1), 3-14.

Nollet, L. M. L., \& Toldrá, F. (2011). Introduction - Offal meat: Definitions, regions, cultures, generalities. Handbook of analysis of edible animal by-products (pp. 105-121). NY: CRC Press.

Nuckles, R. O., Smith, D. M., \& Merkel, R. A. (1990). Meat by-product protein composition and functional properties in model systems. Journal of Food Science, 55(3), 640-643.

Ockerman, H. W., \& Basu, L. (2014). Encyclopedia of meat sciences (2nd ed.). London: Elsevier.

Ockerman, H. W., \& Hansen, C. L. (1988). Animal by-product processing. Chichester, UK: Ellis Horwood Ltd.

Ofori, J. A., \& Hsieh, Y. H. P. (2017). Immunodetection of porcine red blood cell containing food ingredients using a porcine-hemoglobin-specific monoclonal antibody. Food, 6(11), 101

Omana, D.a., Xu, Y., Moayedi, V., \& Betti, M. (2010). Alkali-aided protein extraction from chicken dark meat: Chemical and functional properties of recovered proteins. Process Biochemistry, 45(3), 375-381.

Otto, R.a., Beamer, S., Jaczynski, J., \& Matak, K. E. (2011). The effect of using citric or acetic acid on survival of Listeria monocytogenes during fish protein recovery by isoelectric solubilization and precipitation process. Journal of Food Science, 76(8), 4.

Park, S., Brewer, M. S., Mckeith, F. K., Bechtel, P. J., \& Novakofski, J. (1996). Composition of surimi-like material from beef and pork. Journal of Food Science, 61(4), 717-720.

Parkington, J. K. K., Xiong, Y. L. L., Blanchard, S. P. P., Xiong, S., Wang, B., Srinivasan, S., \& Froning, G. W. W. (2000). Chemical and functional properties of oxidatively modified beef heart surimi stored at 2 C. Journal of Food Science, 65(3), 428-433.

Pasupuleti, V. K., \& Demain, A. L. (2010). Protein hydrolysates in biotechnology. Protein Hydrolysates in Biotechnology, 1-229.

Pearl, G. G. (2005). Animal by-products: Biological and industrial products. In W. G. Pond (Ed.). Encyclopedia of animal science (pp. 19-21). New York: Marcel Dekker Inc.

Pérez-Gálvez, R., Almécija, M. C., Espejo, F. J., Guadix, E. M., \& Guadix, A. (2011). Biobjective optimisation of the enzymatic hydrolysis of porcine blood protein. Biochemical Engineering Journal, 53(3), 305-310.

Piazza, G. J. J., \& Garcia, R. A. A. (2010). Meat \& bone meal extract and gelatin as renewable flocculants. Bioresource Technology, 101(2), 781-787.

Prayson, B., Mcmahon, J., \& Prayson, R. (2008a). Journal article fast food hamburgers: What are we really eating? Annals of Diagnostic Pathology, 12(6), 406-409.

Prayson, B. E., Mcmahon, J. T., \& Prayson, R. A. (2008b). Applying morphologic tech niques to evaluate hotdogs: What is in the hotdogs we eat? Annals of Diagnostic Pathology, 12(2), 98-102.

Primrose, S., Woolfe, M., \& Rollinson, S. (2010). Food forensics: Methods for determining the authenticity of foodstuffs. Trends in Food Science \& Technology, 21(12), 582-590.

Proteus Industries web site Available at http://www.proteusindustries.com, Accessed date: March 2018.

Rogalinski, T., Herrmann, S., \& Brunner, G. (2005). Production of amino acids from bovine serum albumin by continuous sub-critical water hydrolysis. The Journal of Supercritical Fluids, 36(1), 49-58.

Ronaghi, M., Beamer, S., Jaczynski, J., \& Matak, K. E. (2016). A comparison of the bactericidal effectiveness of hydrochloric and acetic acid on Staphylococcus aureus in silver carp during a pH-shift protein recovery process. LWT - Food Science and Technology, 66, 239-243.

Rust, R. E. (1988). Production of edible casings. Edible meat by-products advances in meat research. Vol. 5. Edible meat by-products advances in meat research (pp. 261-274).

Sans, P., \& Combris, P. (2015). World meat consumption patterns: An overview of the last fifty years (1961-2011). Meat Science, 109, 106-111.

Saulnier, L., \& Brunet, E. (1982). Le répertoire de la cuisine. (Leon Jaeggi).

Selmane, D., Christophe, V., \& Gholamreza, D. (2008). Extraction of proteins from slaughterhouse by-products: Influence of operating conditions on functional properties. Meat Science, 79(4), 640-647.

Smeller, L. (2002). Pressure-temperature phase diagrams of biomolecules. Biochimica et Biophysica Acta (BBA) - Protein Structure and Molecular Enzymology, 1595(1), 11-29.

Smyth, A. B., \& Neill, E. O. (1997). Heat-induced gelation properties of surimi from mechanically separated chicken. Journal of Food Science, 62(2), 326-330.

Sobrino-Lopez, A., \& Martin-Belloso, O. (2006). Enhancing inactivation of Staphylococcus aureus in skim milk by combining high-intensity pulsed electric fields and nisin. Journal of Food Protection, 69(2), 345-353.

Spooncer, W. F. (1988). Organds and glands as human food. In A. M. Pearson, \& T. R.
Dutson (Eds.). Edible meat by-products (pp. 197-217). London: Elsevier Applied Science Publishers Ltd.

Srinivasan, S., \& Xiong, Y. L. (1996). Gelation of beef heart surimi as affected by antioxidants. Journal of Food Science, 61(4), 707-711.

Steen, L., Glorieux, S., Goemaere, O., Brijs, K., Paelinck, H., Foubert, I., \& Fraeye, I. (2016). Functional properties of pork liver protein fractions. Food and Bioprocess Technology, 1-11.

Swingler, G. R., \& Lawrie, R. A. (1979). Improved protein recovery from some meat industry by-products. Meat Science, 3(1), 63-73.

Swingler, G. R. R., Naylor, P. E. L. E., \& Lawrie, R. A. A. (1979). Microbial aspects of protein recovery from meat industry by-products. Meat Science, 3(2), 83-95.

Tarté, R. (2009). Ingredients in meat products: Properties, functionality and applications. Ingredients in meat products: Properties (pp. 145-171). Springer Science and Business Media: Functionality and Applications.

Taskaya, L., Chen, Y.-C., \& Jaczynski, J. (2009). Functional properties of proteins recovered from silver carp (Hypophthalmichthys molitrix) by isoelectric solubilization/ precipitation. LWT - Food Science and Technology, 42(6), 1082-1089.

The Commission of the European Communities (2001). The commission of the european communities. Official Journal of the European Communities, 64(Ii), 19-21.

The Commission of the European Communities (2011). Comission regulation (EU) No 142/2011 of 25 February 2011. Official Journal of the European Union, 54, 1-254.

The European Parliament and the Council of the European Union (2004). Regulation (EC) No 853/2004 of the european parliament and of the council of 29 April 2004 laying down specific hygiene rules for food of animal origin. Official Journal of the European, 22(853), 69-74.

The European Parliament and the Council of the European Union (2009). Regulation $1069 / 2009$. Health rules as regards animal by-products and derived products not intended for human consumption. Official Journal of the European Union, 300, 1-33.

Toldrá, F., Mora, L., \& Reig, M. (2016). New insights into meat by-product utilization. Meat Science, 120, 54-59.

Toldrà, M., Parés, D., Saguer, E., \& Carretero, C. (2011). Hemoglobin hydrolysates from porcine blood obtained through enzymatic hydrolysis assisted by high hydrostatic pressure processing. Innovative Food Science \& Emerging Technologies, 12(4), 435-442.

Torrallardona, D., Conde, R., Esteve-García, E., \& Brufau, J. (2002). Use of spray dried animal plasma as an alternative to antimicrobial medication in weanling pigs. Animal Feed Science and Technology, 99, 119-129.

United Nations (2015). Unece standard edible meat co-products. (Geneva).

USDA-FSIS (1999). Saving of blood from livestock as an edible product. Federal register. Vol. 64 No. 246 Part 9 CFR 310.20.

Vann, D. G., \& Mireles Dewitt, C. A. (2007). Evaluation of solubilized proteins as an alternative to phosphates for meat enhancement. Journal of Food Science, 72(1), 72-77.

Vareltzis, P. K., \& Undeland, I. (2012). Protein isolation from blue mussels (Mytilus edulis) using an acid and alkaline solubilisation technique-process characteristics and functionality of the isolates. Journal of the Science of Food and Agriculture, 92(15), 3055-3064.

Von Holst, C., Boix, A., Bellorini, S., Androni, S., \& Serano, F. (2012). Determination of glyceroltriheptanoate ( GTH ) in processed animal by-products by gas chromatography (6th ed.). Vol. 16. Joint Research Centre Institute for Reference Materials and Measurements.

Wang, B., \& Xiong, Y. L. (1998). Functional stability of antioxidant-washed, cryoprotectant-treated beef heart surimi during frozen storage. Journal of Food Science, 63(2), 293-298.

Whitehead, P. A., Church, P. N., \& Knight, M. K. (1993). New animal- derived ingredients In J. Smith (Ed.). Technology of reduced additive foods (pp. 26-59). London: Springer Science and Business Media.

Woolfe, M. (2017). Quarterly newsletter. March 2017. Retrieved June 15, 2017, from http://fera.co.uk/news/resources/documents/FOOD_Authenticity NewsletterMarch17.pdf.

Xian, Z., Chao, Z., Liang, Z., \& Cheng, H. (2008). Amino acids production from fish proteins hydrolysis in subcritical water** supported by the National Natural Science Foundation of China (50578091) and shanghai leading academic discipline project (T-105). Chinese Journal of Chemical Engineering, 16(3), 456-460.

Young, R. H., \& Lawrie, R. A. (1974). Utilization of edible protein from meat industry byproducts and waste. International Journal of Food Science and Technology, 9(2), 171-177.

Young, R. H., \& Lawrie, R. A. (1975). Utilization of edible protein from meat industry byproducts and waste. International Journal of Food Science and Technology, 10(5), 523-532.

Zeugolis, D. I., Paul, R. G., \& Attenburrow, G. (2008). Engineering extruded collagen fibers for biomedical applications. Journal of Applied Polymer Science, 108(5), $2886-2894$.

Zhang, C., Garcia, R. A., \& Piazza, G. J. (2017). Solubilization of meat \& bone meal protein by dilute acid hydrolysis for the production of bio-based flocculant. Food and Bioproducts Processing, 102, 362-366.

Zhao, M., Downey, G., \& O'Donnell, C. P. (2014). Detection of adulteration in fresh and frozen beefburger products by beef offal using mid-infrared ATR spectroscopy and multivariate data analysis. Meat Science, 96(2), 1003-1011.

Zhu, G. Y., Zhu, X., Wan, X. L., Fan, Q., Ma, Y. H., Qian, J., ... Jiang, J. H. (2010). Hydrolysis technology and kinetics of poultry waste to produce amino acids in subcritical water. Journal of Analytical and Applied Pyrolysis, 88(2), 187-191.

Zin, G., Penha, F. M., Rezzadori, K., Silva, F. L., Guizoni, K., Petrus, J. C. C., ... Di Luccio, M. (2016). Fouling control in ultrafiltration of bovine serum albumin and milk by the use of permanent magnetic field. Journal of Food Engineering, 168, 154-159. 